Indonesian Journal of Global Health Research

Volume 3 Number 3, August 2021, pp. 333 - 340

e-ISSN 2715-1972; p-ISSN 2714-9749

http://jurnal.globalhealthsciencegroup.com/index.php/IJGHR

\title{
APPLICATION OF ECONOMY TOKEN TO SELF-CARE OF MENTAL ILLNESS PATIENTS
}

\author{
Saufa Yuthika Syahdiba ${ }^{1}$, Wardah ${ }^{1}$, Sri Yanti ${ }^{1}$, Eka Malfasari ${ }^{1 *}$, Bayu Azhar ${ }^{1}$, Ulia Nelma $^{2}$, Aulia Akbar $^{2}$ \\ ${ }^{1}$ Nursing Program, STIKes Payung Negeri Pekanbaru, Jalan Tamtama No.6, Labuh Baru Timur, Payung Sekaki, \\ Kecamatan, Labuh Baru Tim., Kec. Pekanbaru Kota, Kota Pekanbaru, Riau 28292, Indonesia \\ ${ }^{2}$ Rumah Sakit Jiwa Tampan, Provinsi Riau, Jl. HR. Soebrantas Panam No.KM 12.5, Simpang Baru, Kec. \\ Tampan, Kota Pekanbaru, Riau 28293, Indonesia \\ *mizzeka18@gmail.com
}

\begin{abstract}
Self-care deficit is most of problem in psychiatric nursing diagnoses that characterized by decreased ability to perform activities consisting of bathing, dressing, decorating, eating, toileting or personal hygiene independently. One of the efforts that can be done to reduce this problem is behavioral therapy: Token Economy. The purpose of this study was to identify the effect of behavioral therapy: Token Economy on selfcare of mental patients with self-care deficits at the Tampan Mental Hospital, Riau Province. This type of research is quantitative with a quasi-experimental design. The sample in this study was 25 people who were patients with self-care deficits that diagnosed by data from Sebayang Ward Tampan Mental Hospital, Riau Province. The sampling technique is accidental sampling. Data was proceeded by computerized univariate and bivariate analysis. Statistical test using Wilcoxon test after the previous normality test. The results showed that there was a decrease in the level of dependence on self-care. The $\mathrm{Z}$ value shows the effect of behavioral therapy: token economy after and before the intervention of $-4,414$. From the results of the statistical test, it was found that the alpha value $(\mathrm{p}<0.05)$, means that there is a significant effect before and after behavioral therapy: the token economy.
\end{abstract}

Keywords: behavioral therapy; mental disorders; self-care; token economy

\begin{tabular}{|c|c|c|}
\hline $\begin{array}{c}\text { First Received } \\
14 \text { July } 2021\end{array}$ & $\begin{array}{c}\text { Revised } \\
\text { 20 July } 2021\end{array}$ & $\begin{array}{c}\text { Accepted } \\
24 \text { July } 2021\end{array}$ \\
\hline $\begin{array}{c}\text { Final Proof Receivec } \\
\text { 25 July } 2021\end{array}$ & & $\begin{array}{l}\text { ped } \\
2021\end{array}$ \\
\hline \multicolumn{3}{|c|}{$\begin{array}{l}\text { How to cite (in APA style) } \\
\text { Syahdiba, S., Wardah, W., Malfasari, E., Yanti, S., Azhar, B., Nelma, U., \& Akbar, A. (2021). Application of } \\
\text { Economy Token to Self-Care of Mental Illness Patients. Indonesian Journal of Global Health Research, 3(3), } \\
\text { 333-340. https://doi.org/10.37287/ijghr.v3i3.505 }\end{array}$} \\
\hline
\end{tabular}

\section{INTRODUCTION}

According to the National Alliance of Mental Illness (NAMI) (2015) mental disorders are conditions that change thoughts, feelings and behaviors that affect daily life. Patients with mental disorders have different signs and symptoms even with the same medical diagnosis. One of the symptoms that often appears in patients with mental disorders is not wanting to do self-care which in the nursing diagnosis is a self-care deficit. Self-care deficit is a nursing diagnosis characterized by impaired ability to perform activities consisting of bathing, dressing, decorating, eating, toileting. or self-hygiene independently (NANDA, 2012). One effort to change patient behavior is to do a token economy.

The token economy is one of the interventions to change negative behavior and reduce positive behavior by using tokens (signs) (Nasir \& Muhith, 2011). Based on the results of research by Gholipur, et al (2012) stated that the Token Economy was able to reduce negative symptoms by $58.8 \%$ in schizophrenia patients. Patients with self-care deficits at the Tampan Mental Hospital in Riau Province have increased every year. Based on recapitulation data in 
2011 as many as 104 people (9.7\%), in 2012 as many as 335 people (7.3\%), in 2013 as many as $342(9.8 \%)$ and in 2014 as many as 357 people (26.6\%) (LAKIP RSJ Handsome, 2014). The Tampan Mental Hospital of Riau Province has five rooms of the Professional Nursing Practice Model (MPKP) with nursing problems of self-care deficit, namely: in the Kuantan room as many as 7 patients $(22.6 \%)$, in the Siak room as many as 6 patients $(27.3 \%)$, in the Sebayang room there were 2 patients $(5.5 \%)$, in the Indragiri room there were 11 patients $(36.6 \%)$ and in the Kampar room 1 patient (5\%).

Based on a survey of 5 patients in the Indragiri room, 2 patients looked shabby (40\%), 4 patients smelled (80\%), 3 patients often scratched their heads (due to head lice) $(60 \%), 4$ patients were untidy (80\%), 3 patients had food scattered $(60 \%)$ and 2 patients did not clean themselves well after defecating $(40 \%)$. Based on the description above, the author is interested in further researching the effect of behavioral therapy: Token Economy on self-care of mental patients with self-care deficits at the Tampan Mental Hospital, Riau Province.

\section{METHOD}

This research is a quantitative study with a quasi-experimental design (experimental), which is a form of research design using a quasi-experimental design (quasi-experimental) with a One Group Pretest-Posttest design. The location of the research was carried out in the Siak, Kampar, Sebayang, Kuantan and Indragiri inpatient wards at the Tampan Mental Hospital, Riau Province. The reason for choosing this location is because the Tampan Mental Hospital is the only mental hospital in Riau province. The population in this study were patients who experienced self-care deficits in the inpatient rooms of the Pekanbaru Tampan Mental Hospital. The number of samples in this study were 25 patients. The sampling technique in this study was accidental sampling. The sample was selected by nursing diagnose in medical records and based from researcher observation. Data was analyzed by univariate and bivariate analysis. General data that consist of caracteristics of respondent were analyzed by univariate analysis. For data effectivity of token economy for self care defisite was analyzed by bivariate using Wilcoxon analysis.

\section{RESULTS}

Table 1.

Distribution of Respondents by Age

\begin{tabular}{lcc}
\hline \multicolumn{1}{c}{ Age } & f & $\%$ \\
\hline Late adolescence (17-25 years) & 7 & 28 \\
Early adulthood (26-35 years) & 6 & 24 \\
Late adulthood (36-45 years) & 8 & 32 \\
Early elderly (46-55 years) & 1 & 4 \\
Late elderly (56-65 years) & 3 & 12 \\
\hline
\end{tabular}

The description of the distribution of respondents based on age in this study was obtained from 25 as many as 8 respondents (32\%) including late adults (36-45 years).

Table 2.

Distribution of Respondents by Gender

\begin{tabular}{lcc}
\hline Gender & $\mathrm{f}$ & $\%$ \\
\hline Male & 19 & 76 \\
Female & 6 & 24 \\
\hline
\end{tabular}


Table 3.

Distribution of Respondents Based on Marital Status

\begin{tabular}{lcc}
\hline Marital Status & $\mathrm{f}$ & $\%$ \\
\hline Not Married & 16 & 64 \\
Married & 8 & 32 \\
Divorced & 1 & 4 \\
\hline
\end{tabular}

Table 4.

Distribution of Respondents Based on Recent Education

\begin{tabular}{lcc}
\hline \multicolumn{1}{c}{ Education } & $\mathrm{f}$ & $\%$ \\
\hline Not in school & 1 & 4 \\
SD & 15 & 60 \\
SMP & 5 & 20 \\
SMA & 3 & 12 \\
Universities & 1 & 4 \\
\hline
\end{tabular}

Most of the respondents' last education was elementary school graduates as many as 15 respondents $(60 \%)$.

Table 5.

Distribution of Respondents by Level of Self-Care Ability: Bathing Before and After Behavioral Therapy: Token Economy

\begin{tabular}{lcccc}
\hline & \multicolumn{4}{c}{ Bath } \\
\cline { 2 - 5 } \multicolumn{1}{c}{ Level of Self-care Ability } & \multicolumn{3}{c}{ Pre } & \multicolumn{2}{c}{ Post } \\
\cline { 2 - 5 } & $\mathrm{f}$ & $\%$ & $\mathrm{f}$ & $\%$ \\
\hline Fully independent & 0 & 0 & 21 & 84 \\
\hline Requires tools or assistive devices & 0 & 0 & 0 & 0 \\
\hline Requires help from others for assistance, supervision and education & 15 & 60 & 4 & 16 \\
\hline Requires help from other people and equipment or assistive devices & 10 & 40 & 0 & 0 \\
\hline Dependence, unable to participate in activities & 0 & 0 & 0 & 0 \\
\hline
\end{tabular}

Table 6

Distribution of Respondents by Level of Self-Care Ability: Dressing Before and After Behavioral Therapy: Token Economy

\begin{tabular}{lcccc}
\hline & \multicolumn{3}{c}{ Berhias } \\
\cline { 2 - 5 } The level of ability of Care & \multicolumn{3}{c}{ Pre } & \multicolumn{2}{c}{ Post } \\
\cline { 2 - 5 } & $\mathrm{f}$ & $\%$ & $\mathrm{f}$ & $\%$ \\
\hline Independent Full & 0 & 0 & 16 & 64 \\
\hline Requires equipment or tools & 0 & 0 & 9 & 36 \\
\hline Need help other people to help, supervision and education & 13 & 52 & 0 & 0 \\
\hline Need help other people and equipment or assistive devices & 12 & 48 & 0 & 0 \\
\hline Dependence, unable to participate in activities & 0 & 0 & 0 & 0 \\
\hline
\end{tabular}

Table 5, it can be seen that the level of self-care ability: bathing before behavioral therapy: token economy the most 15 respondents $(60 \%)$. After the behavioral therapy intervention: 
token economy, respondents with the level of self-care ability: fully independent bathing were 21 people (84\%). Table 6 distribution of self-care ability levels: decorated with respondents before behavioral therapy: token economy the mostis needing the help of others for assistance, supervision and education as many as 13 people (52\%). Distribution of self-care ability level: fully self-made after behavior therapy: token economy as many as 16 people (64\%). Table 7 distribution of self-care ability levels: eating before behavioral therapy: token economy the mostis need help from others for assistance, supervision and education as many as 19 people (76\%). After the behavioral therapy intervention: token economy, respondents with the level of self-care ability: fully independent eat as many as 23 people (92\%).

Table 7.

Distribution of Respondents by Level of Self-Care Ability: Eating Before and After Behavioral Therapy: Token Economy

\begin{tabular}{lcccc}
\hline & \multicolumn{3}{c}{ Eating } \\
\cline { 2 - 5 } Level of Self-Care Ability & \multicolumn{3}{c}{ Prest } \\
\cline { 2 - 5 } & $\mathrm{f}$ & $\%$ & $\mathrm{f}$ & $\%$ \\
\hline Fully independent & 6 & 24 & 23 & 92 \\
\hline Requires equipment or assistive devices & 0 & 0 & 0 & 0 \\
\hline Requires help from others for assistance, supervision and education & 19 & 76 & 2 & 8 \\
\hline Requires help from other people and equipment or assistive devices & 0 & 0 & 0 & 0 \\
\hline Dependence, unable to participate in activities & 0 & 0 & 0 & 0 \\
\hline
\end{tabular}

Table 8.

Distribution of Respondents by Level of Self-Care Ability: Elimination Before and After Behavioral Therapy: Token Economy

\begin{tabular}{lcccc}
\hline \multirow{2}{*}{ Level of Self-Care Ability } & \multicolumn{3}{c}{ Elimination } \\
\cline { 2 - 5 } & \multicolumn{3}{c}{ Pre } & \multicolumn{2}{c}{ Post } \\
\cline { 2 - 5 } & $\mathrm{f}$ & $\%$ & $\mathrm{f}$ & $\%$ \\
\hline Fully independent & 7 & 28 & 21 & 84 \\
\hline Requires tools or assistive devices & 0 & 0 & 0 & 0 \\
\hline Requires help from others for assistance, supervision and education & 18 & 72 & 4 & 16 \\
\hline Requires help from other people and equipment or assistive devices & 0 & 0 & 0 & 0 \\
\hline Dependence, unable to participate in activities & 0 & 0 & 0 & 0 \\
\hline
\end{tabular}

Table 8 distribution of self-care ability levels: elimination before behavioral therapy: token economy the mostis 18 people need help from other people for assistance, supervision and education $(72 \%)$. After the behavioral therapy intervention: token economy, respondents with the level of self-care ability: full independent elimination were 21 people (84\%). Table 9, it shows a comparison of the level of self-care ability: bathing before and after behavior therapy: token economy with negative ranks totaling 25 respondents. All respondents showed a higher level of self-care skills than before behavioral therapy: token economy.

Table 10 shows the comparison of the level of self-care ability: decorating before and after behavior therapy: token economy with negative ranks totaling 25 respondents. All respondents showed a higher level of self-care skills than before behavioral therapy: token economy. Table 11 shows the comparison of the level of self-care ability: bath before and after behavior therapy: token economy with negative ranks totaling 17 respondents. All respondents showed a higher level of self-care skills than before behavioral therapy: token economy. 
Table 9.

Effect of Behavioral Therapy: Token Economy on Self-Care: Bathing of Mentally Impaired Patients with Self-Care Deficits

\begin{tabular}{lcccccc}
\hline Self-care Ability & \multicolumn{3}{c}{ Ranks } & \multicolumn{2}{c}{ Test Statistic } \\
\cline { 2 - 7 } Level: Bathing & Ranks & $N$ & Mean Rank & Sum of Ranks & $Z$ & P value \\
\hline $\begin{array}{l}\text { Before and after } \\
\text { behavior therapy: }\end{array}$ & Negative Ranks & 25 & 13 & 325 & $-4,497$ & 0.00 \\
\cline { 2 - 7 } token economy & Positive Ranks & 0 & 0.00 & 0.00 & 0.00 & 0.00 \\
\cline { 2 - 7 } & Ties & 0 & 0.00 & 0.00 & 0.00 & 0,00 \\
\hline
\end{tabular}

Table 10.

Effect of Behavior Therapy: Token Economy on Self-Care: Decorated Mental Disorder Patients with Self-Care Deficits in Inpatient Mental Hospital Handsome

\begin{tabular}{lccccccc}
\hline $\begin{array}{l}\text { Level of Self- } \\
\text { Care Ability: } \\
\text { Decorated }\end{array}$ & Ranks & $N$ & Mean Rank & Sum of Ranks & Z & P value \\
\hline $\begin{array}{l}\text { Before and after } \\
\text { behavior therapy: } \\
\text { token economy }\end{array}$ & Negative Ranks & 25 & 13 & 325 & $-4,582$ & 0.00 \\
\cline { 2 - 8 } & Positive Ranks & 0 & 0.00 & 0.00 & 0.00 & 0.00 \\
\hline
\end{tabular}

Table 11.

Effect of Behavior Therapy: Token Economy To Care: Eating Patient Mental Disorder with deficit Care of Yourself

\begin{tabular}{lcccccc}
\hline Level Capabilities & \multicolumn{2}{c}{ Ranks } & \multicolumn{2}{c}{ Test Statistic } \\
\cline { 2 - 7 } Self Care: Spot & Ranks & $N$ & Mean Rank & Sum of Ranks & Z & P value \\
\hline Before and after & Negative Ranks & 17 & 9.00 & 153 & $-4,123$ & 0.00 \\
\cline { 2 - 7 } $\begin{array}{l}\text { behavior therapy: } \\
\text { token economy }\end{array}$ & Positive Ranks & 0 & 0.00 & 0.00 & 0.00 & 0.00 \\
\cline { 2 - 7 } & Ties & 8 & 0.00 & 0.00 & 0.00 & 0,00 \\
\hline
\end{tabular}

Table 12.

Effect of Behavioral Therapy: Token Economy on Self-Care: Elimination of Mental Disorder Patients with Self-Care Deficits in Inpatient Rooms at a Mental Hospital Handsome

\begin{tabular}{lcccccc}
\hline Self-care Ability & \multicolumn{3}{c}{ Ranks } & \multicolumn{3}{c}{ Test Statistic } \\
\cline { 2 - 8 } Level: Elimination & Ranks & $N$ & Mean Rank & Sum of Ranks & Z & P value \\
\hline Before and after & Negative Ranks & 14 & 7.50 & 105 & $-3,742$ & 0.00 \\
\cline { 2 - 8 } $\begin{array}{l}\text { behavior therapy: } \\
\text { token economy }\end{array}$ & Positive Ranks & 0 & 0.00 & 0.00 & 0.00 & 0.00 \\
\cline { 2 - 7 } & Ties & 11 & 0.00 & 0.00 & 0.00 & 0,00 \\
\hline
\end{tabular}

Table 12 shows the comparison of the level of self-care ability: elimination before and after behavior therapy: token economy with negative ranks totaling 14 respondents. All respondents showed a higher level of self-care skills than before behavioral therapy: token economy.

\section{DISCUSSION}

Based on the results of the study, the number of more male respondents than female. The large proportion of male sex is due to the fact that $76 \%$ of clients treated at the Tampan Mental Hospital in Riau Province are generally male. Based on the Ministry of Health of the Republic of Indonesia (2007), sufferers of severe mental disorders are more common in men than women. The coping mechanisms used by male and female respondents are different. The same goes for self-care. Female respondents are more concerned with body image because 
basically women tend to want to look beautiful and attractive in the eyes of the opposite sex. The level of a person's self-care ability is influenced by age, stage of development, life experience, sociocultural background, health and available resources (Marriner, 2001 in Andayani, 2012). Late adulthood is a person who already has physical and mental maturity. If a person fails to pass the developmental tasks in his life, it will affect the emotions that lead to self-care deficits. Based on Status marriage, respondents who are not married as many as 16 people $(64 \%)$. Individuals who do not have a partner or experience divorce are at high risk of experiencing mental disorders that can hinder their ability to meet self-care needs (Stuart \& Sundeen, 2005 in Andayani, 2012). Respondents whose own lives will have an impact on their psyche. When it comes to age, many clients are in the range of late adolescence, early adulthood and late adulthood where clients have a developmental task that must be passed, namely developing relationships with the opposite sex in marriage bonds. Respondents who are not fulfilled or fail to fulfill their developmental tasks have difficulty performing self-care.

Knowledge of hygiene affects the practice of self-care in respondents. If the respondent knows about the risk of self-care deficit, then the respondent will carry out self-care properly and correctly. However, from the results of the study, it was found that there were several respondents who did not know about this and this was motivated by their low education. Sasmita's research (2011) on the effect of themethod token economy on self-care activities: bathing and decorating in mental patients, it was found that respondents experienced an increase in personal hygiene activities including: bathing, brushing teeth, washing hair, using soap in the shower, and cut nails.

Patients are able to carry out self-care properly and correctly after the intervention, because of the rewards given. This is also supported by the role of nurses who always direct and supervise patients in bathing activities. Stevi's (2006) research on the effectiveness of giving tokens to personal hygiene activities in mental patients, stating that patients experience good personal hygiene activities after being given themethod token economy. Self-care ability can be increased because it is supported by tokens for every positive behavior that is carried out. Laili's research (2014) on the effect of independent activities: personal hygiene on the independence of patients with self-care deficits in mental patients that after independent activities: personal hygiene (eating) the results ofindependence personal hygiene (eating) were in the good category as much as $20(71.4 \%)$.

There is an increase in self-care ability: eating is due to praise and rewards given. Therefore, when the intervention was carried out they could accept it well. Septiabudi (2006) regarding the effect of giving rewards to patients with self-care deficit stating that patients experience an increase in personal hygiene activities after being given a reward accompanied by praise for carrying out personal hygiene activities. The increase in personal hygiene in patients was caused by the praise given in the form of reinforcement positive(rewards) given during the study. the research of Kokaridas, et al (2013), where the results of this pilot study show that in general the token economy is able to motivate schizophrenic patients to improve their quality of life.

Based on the results and theory above, the researcher concludes that there is a patient's concern for himself and because of therewardsand understanding received by the patient about what has been taught by the researcher so that it can be applied properly by the patient. According to Sadock et.al, 2007 in Gholipur, Gholinia \& Taheri, (2012), behavioral therapy and rehabilitation, helps individuals to regain skills and behavior patterns. This is in line with the research conducted by Gholipur, et al in (2011), where the results showed that the 
strengthening approach with tokens was higher and significantly more effective thanexerciseto reduce negative symptoms in schizophrenic patients. The researcher concluded that there was an increase in self-care ability: eating was due to self-motivation, and because of the understanding received by the patient about what the researcher had taught so that it could be applied well by the patient. According to NANDA (2012) and Wilkinson (2011), self-care deficit: elimination is a barrier to the ability to perform, complete, or complete selfelimination activities/activities (Characteristic limitation of self-care deficit: elimination is the inability to perform proper elimination hygiene, flush the toilet, go to the toilet, take off or use clothes for elimination, get off the toilet or to sit/get up from the toilet, clean up after elimination. This is in accordance with research by Gholipur et.al (2011) and Kokaridas et.al (2013) that therapy behavior: the token economy is able to reduce negative symptoms and motivate clients with mental disorders.

The researcher concluded that the increase in personal hygiene activities in patients was caused by the client being given praise when the patient carried out personal hygiene activities. The praise given was accompanied by reward for the patient. Nasir \& Muhith, (2011), the token economy is a form of behavior modification designed to increase desired behavior and reduce unwanted behavior by using tokens (signs). This is in accordance with the research of Gholipur et. al (2011) and Kokaridas et. al (2013) that behavioral therapy: token economy is able to reduce negative symptoms and motivate clients with mental disorders. The researcher concluded that the patient's level of ability in self-care: bathing could increase after the intervention due to the positive reception from the patient. In addition, patients are also motivated by the rewards of the number of tokens obtained (Nasution, Daulay \& Wahyuni, 2021)

\section{CONCLUSIONS}

The ability of mental patients with mental health deficits self-care in self-care: bathing before being given behavioral therapy: Token Economy the majority of respondents need help from others for assistance, supervision and education. After being given behavioral therapy: Token Economy, the level of self-care ability of the majority of patients became fully independent. The ability of mental patients with self-care deficits in self-care: make-up before being given behavioral therapy: Token Economy the majority of respondents need the help of others for assistance, supervision and education. After being given behavioral therapy: Token Economy, the level of self-care ability of the majority of patients became fully independent. The ability of mental patients with self-care deficits in self-care: eating before being given behavioral therapy: Token Economy the majority of respondents need help from others for assistance, supervision and education. After being given behavioral therapy: Token Economy, the level of self-care ability of the majority of patients became fully independent. From statistical tests, it is known that there are. The ability of mental patients with self-care deficits in self-care: elimination before being given behavioral therapy: Token Economy the majority of respondents need help from others for assistance, supervision and education. After being given behavioral therapy: Token Economy, the level of self-care ability of the majority of patients became fully independent.

\section{REFERENCES}

Andayani, Sri. (2012). Client Characteristics Schizophrenia relationship with Level Capabilities in Space Care Inpatient Psychiatric Hospital Women Marzoeki MahdiBogor.University of Indonesia Library: OPAC. www.lib.ui.ac.id. 
Ministry of Health, Republic of Indonesia. (2007). Ministry of Health Basic Health Research 2007.

Gholipur, Gholinia \& Taheeri. (2012). Token Reinforcement Therapeutic Approach is More Effective than Exercise for Controlling Negative Symptoms of Schizophrenic Patients: A Randomized Controlled Trial. International Journal of Preventive Medicine, Vol. 3 No. 7. http://www.ncbi.nlm.nih.gov/pubmed/22891147. obtained on November 8, 2015.

Kokaridas, et.al. (2013). The Effect of Token Economy System Program and Physical Activity on Improving Quality of Life of Patients with Schizophrenia: a Pilot Study. American $\begin{array}{llllll}\text { Journal of Applied Psychology } & \text { Nol. }\end{array}$ http://www.ncbi.nlm.nih.gov/pubmed/22891147.pdf retrieved November 8, 2015.

Laili. (2014). The Effect of Independent Activities: Personal Hygiene on Self-Care Deficit Patients In Mental Disorder Patients. Journal of Nursing and Midwifery. pmb.stikestelogorejo.ac.id/e-journal/index.php/ilmukeperawatan/. Retrieved March 25, 2016.

Government Installation Performance Accountability Report (LAKIP). (2014). Pekanbaru:Handsome Mental Hospital

NAMI. (2015). Mental Health Conditions. http://www.nami.org/Learn-More/Mental-HealthConditions. obtained on October 20, 2015

NANDA International. (2012). Nursing Diagnosis: Definition and Classification 2012-2014. (Translated by: Sumarwati, M., Widiarti, D., \& Tiar E.). Jakarta: EGC.

Nasir, A. \& Muhith, A. (2011). Psychiatric Nursing Fundamentals: An Introduction and Theory. Jakarta: Salemba Medika.

Nasution, M. L., Daulay, W., \& Wahyuni, S. E. (2021). Implementation of Behavioral Therapy (Economic Token) on the Ability of People with Mental Disorders in Fulfilling Self-Cleaning (Personal Hygiene) in Medan Sunggal Subdistrict. Open Access Macedonian Journal of Medical Sciences, 9(T3), 84-86. https://doi.org/10.3889/oamjms.2021.6307

Potter, PA \& Perry, AG (2009). Fundamentals of Nursing ${ }^{7 t h}$ Ed. Singapore: Elsevier Inc.

Sasmita, H. (2011). The Influence of Token Economy Method on Self-Care Activities: Bathing and Decorating at Prof. Mental Hospital. HB. Sa'anin Padang. http://jurnal.fkep.unand.ac.id obtained on November 21, 2015.

Septiabudi. (2006). About the Effectiveness of Giving Tokens on Personal Hygiene Activities in Mentally Impaired Patients. http://www.scribd.com . obtained on March 20, 2016.

Stevi. (2006). The Effectiveness of Giving Tokens Towards Personal Hygiene Activities In Mental Disorder Patients. http://www.scribd.com . obtained on 15 March 2016.

Wilkinson, Judith M. (2011). Nursing Diagnosis Handbook: NANDA Diagnosis, NIC Interventions, and NOC Outcome Criteria. (Translated by: Wahyuningsih, E.). Jakarta: EGC. 
World Health Organization. (2005). Human Resources and Training in Mental Health: Mental Health Policy and Service Guide Package. China: WHO Publishing. 